\title{
FORUM
}

Submitted 08.31.2017. Approved 12.26.2017

Evaluated through a double-blind review process. Guest Scientific Editors: Marina Heck, Jeffrey Pilcher, Krishnendu Ray, and Eliane Brito

Original version

DOI: http://dx.doi.org/10.1590/So034-759020180303

\section{CONVIVENCIA: A SOLUTION TO THE HALAL/ PORK TENSION IN SPAIN?}

\author{
Convivência: Uma solução para a tensão de halal/carne de porco na Espanha? \\ Convivencia: ¿Una solución para la tensión halal/cerdo en España?
}

\begin{abstract}
This work illuminates the connection between foodways and identity forging in Spain's migration context. The concern of Moroccan and Pakistani Muslims over maintaining halal food practices conflicts with Spain's reliance on and celebration of Iberian ham. This "two food cultures conflict," which I conceptualize as a halal/pork binary, can be traced back to the $15^{\text {th }}$ century Spanish reconquista. However, Moroccan restaurateurs' current revival of the convivencia (coexistence) narrative, their emphasis on a collective Andaluzi identity, and tapasization and halalization of Moroccan-Muslim and Spanish foodways are possible solutions to this tension. This identity work in the restaurant allows them to reconcile the cultural, religious, and gastronomic tensions between Muslims and non-Muslims in Spain and rewrites halal foodways into the Spanish foodscape.
\end{abstract}

KEYWORDS | Immigrants, identity, food, halal, Muslim.

\section{RESUMO}

Este trabalho ilumina a conexão entre hábitos alimentares e forjamento de identidade no contexto da imigração na Espanha. A preocupação dos muçulmanos marroquinos e paquistaneses com a manutenção de práticas alimentares halal entra em conflito com a dependência e celebração do presunto ibérico na Espanha. Esse "conflito de duas culturas alimentares", o que conceituo como um binário halal/carne de porco, pode ser rastreado até a reconquista espanhola no século XV. No entanto, o restabelecimento atual dos proprietários de restaurantes marroquinos da narrativa da convivência (coexistência), sua ênfase numa identidade coletiva de Andaluzia e sua tapasização e halalização de alimentos marroquinos muçulmanos e espanhóis servem como soluções possíveis para essa tensão. Este trabalho de identidade nos restaurantes permite-Ihes reconciliar as tensões culturais, religiosas e gastronômicas entre muçulmanos e não muçulmanos na Espanha e reescreve os alimentos halal dentro da paisagem alimentar espanhola.

PALAVRAS-CHAVE / Imigrantes, identidade, hábitos alimentares, halal, muçulmanos.

\section{RESUMEN}

Este trabajo ilumina la relación entre las prácticas culinarias y la forja de identidad en el contexto migratorio de España. La preocupación de los musulmanes marroquíes y paquistaníes de mantener prácticas culinarias halal entra en conflicto con la dependencia y celebración española del jamón ibérico. Este "conflicto de dos culturas culinarias", lo que conceptualizo como un binario halal/cerdo, se remonta a la reconquista española del siglo XV. Sin embargo, el revival actual de los propietarios de restaurantes marroquíes de la narrativa de la convivencia (coexistencia), su énfasis en una identidad andaluza colectiva y la conversión de prácticas culinarias marroquíes-musulmanas y españolas en platos estilo tapas y halal sirven como posibles soluciones a esta tensión. Este trabajo de identidad en el restaurante les permite reconciliar las tensiones culturales, religiosas y gastronómicas entre musulmanes y no musulmanes en España y reescribe las prácticas culinarias halal en el marco gastronómico español.

PALABRAS CLAVE | Inmigrantes, identidade, prácticas culinárias, halal, musulmán.

LEELA RIESZ

resz@alumni.conncoll.edu ORCID: 0000-0001-5347-4451 ${ }^{1}$ Connecticut College, New London, CT, United States of America 


\section{INTRODUCTION}

Mohammad, what does the food you serve in your restaurant mean to you?

The same as what your food is to you. My food is part of my life and my culture. I want to bring and show this culture to many people. Southern Spain differs from Europe, because it is a mixture of Christians and Muslims, an incredible mixture...I do not eat any meat that is not halal. I am not going to obligate someone who likes pork to not eat it. Even today, not many Spanish restaurants offer halal meat. Notice that all the people at this table, that table, and that table were Moroccan, and that they were looking for halal food. They see on the door that there is halal food and they enter. (Field notes)

This snapshot of a discussion with Mohammad, a Moroccan restaurant owner, encapsulates the major themes to be explored. Foodways and the restaurant space serve as a lens through which to investigate the experiences of Muslim immigrants, primarily restaurant owners and workers from Morocco and Pakistan, and their negotiation of identity in Southern Spain. Here, Mohammad, a practicing Muslim and the owner of Fez restaurant in Seville, describes his adherence to halal food practices and the need for more halal food establishments in Spain. Halal, which means "permissible," refers to food, particularly meat that has been ritually prepared or slaughtered according to Islamic dietary law. Conversations with restaurant workers and owners reveal a tension between Spanish and Muslim foodways that is historically rooted. Spain offers an intriguing case study given that the halal food practices of Muslims conflict with Spain's dominant food culture, namely its reliance on and celebration of jamón iberico (Iberian ham) and other pork products. Here, this tension is conceptualized as a halal/pork binary. Most important, conversations uncover restaurateurs' use of food narratives to directly or indirectly address this tension and signal a more collective vision of relations between Spanish nationals and Muslim immigrants. Attention turns to two restaurateurs' references to the period when Muslims ruled Spain, also referred to as "al-Andaluz," between 711 and 1492. For example, Mohammad's above recollection of convivencia, the period beginning in the year 711 in which Muslims, Christians, and Jews coexisted in Southern Spain, is notable, because it allows him to underscore Muslims' place in the Spanish context. This article later explores how the convivencia narrative is implemented by restaurateurs and recognized by food scholars to signal the historical presence of halal foodways in Southern Spanish daily life. Food scholars who investigate convivencia define it as a period of relative tolerance characterized by a co-mingling of Muslim and Christian foodways that existed before the reconquista, the inquisition, and the expulsion of the moriscos (Muslim converts to Christianity) (Constable, 2013).

The restaurant is a significant locale for the construction and expression of immigrant identity in terms of negotiating a Muslim, Pakistani, or Moroccan identity in Spain. Public food spaces run by immigrants are valuable sites of inquiry for investigating their efforts to position themselves in the Spanish context. In the United States and some European countries, a well-established area of scholarship exists that examines the connection between food, identity, and migration. (For examples of this scholarship, readers are referred to the work of Hasia Diner, David Beriss, Carole Counihan, Fedora Gasparetti, Jeffrey Pilcher, and Krishnendu Ray, among others.) Furthermore, an emerging body of literature focuses on halal food production, marketing, ritual slaughter, food establishments, and their relevance in the lives of Muslim immigrants living in Europe (Bonne, Vermeir, Bergeaud-Blackler, \& Verbeke, 2007; Bonne \& Verbeke, 2008; Wright \& Annes, 2013; Bergeaud-Blackler, 2007; Fischer, 2011). For example, John Lever and Mara Miele refer to the halal industry as an emerging "religious marketplace" that represents the "supply side theory of religion" (Lever \& Miele, 2012, p. 1). Drawing on the voices of restaurateurs, this article highlights how their negotiation of halal food practices and engagement with and/or avoidance of aspects of Spanish food culture are connected to place making in the new country. This analysis looks at the halal concept not only as a product in an emerging “diasporic, religious market” (Bergeaud-Blackler, Fischer, \& Lever, 2016, p. 13), but as a foodway and food behavior that can be traced to the period of al-Andaluz, one that is measured against Spain's mainstream food culture and raises questions of belonging in contemporary times. Thus, this exploration clarifies the historical presence of halal food practices in medieval Spain and highlights restaurateurs' strategic references to this food history. While my prior work explores the dependence of Muslim immigrants on halal kebab fast-food restaurants and Pakistani Muslims' participation in this halal food industry, this article examines two Moroccan restaurants that adhere to halal dietary law, but tend to cater to a wider clientele with a higher socioeconomic status. Owing to their North African heritage, both restaurant owners are able to tap into a historical narrative, which Pakistani Muslims do not have the same access to. Using a "two food culture concept" as a guiding principle, I explore the tensions that emerge when immigrants' food practices are challenged by their surrounding environment. This concept of 
"conflicting food cultures" reflects the circumstances interviewees described to me, that is, being surrounded by foodways that are inimical to one's religious and gustatory traditions. Exploring restaurateurs' solutions to this tension, I uncover the symbolic meanings attached to foodways and the restaurant space as well as restaurateurs' attempts to reconcile the cultural, religious, and gastronomic fault lines between non-Muslims and Muslims in Spain.

\section{METHODS AND RESEARCH SITE}

This article draws on a larger work written in 2016, and is based on semi-structured ethnographic interviews and participant observation carried out during spring and summer 2015 in Seville and Almería, Spain. The interviews were recorded and transcribed. Pseudonyms are used to protect the privacy of interviewees. Almería, a coastal city with a population of roughly 190,000 people, is Andalucía's most eastern capital. In recent years, it has become a heavy tourist destination. The highest concentration of Muslims within Andalucía is in the province of Almería, the majority arriving from Morocco (Alméria City, 2016). According to a recent census, the number of Muslims in Spain is close to 1.6 million, 1.1 million of who are foreigners and 460,000 Spanish Muslims. Pakistanis constitute around $5 \%$ of the Muslim population. Moroccans remain the longest-standing immigrant population in Spain, constituting approximately $70 \%$ of the total Muslim population (Euro-Islam, 2013; Bravo, 2014). Between $70 \%$ and $75 \%$ of Spaniards identify as Roman Catholic Christians. While many self-identified Catholics report not attending mass very often, Catholicism as a popular religion is unmistakable, especially during Saint's days and Spain's Holy Week (Semana Santa) (Pariona, 2017).

\section{HISTORICAL BACKGROUND: FROM CONVIVENCIA TO RECONQUISTA}

Before investigating Muslims' current negotiation of halal food practices and their encounters with Spanish food culture, it is useful to consider the significance of pork in Spain to uncover how its omnipresence reinforces a cultural barrier. Pork was once a marker of Catholicism, and Iberian ham is a national culinary emblem in contemporary Spain. In Pig Perfect, Peter Kaminsky notes the historical significance of the dehesa, the land upon which Iberian pigs are raised. The institution of the dehesa can be traced to the Christian and Muslim conflict. Kaminsky explains that dehesa comes from the word defensa, which denotes "land that could be closed in and defended by the noblemen to whom it belonged" (Kaminsky, 2005, p. 90). Christian nobility were commonly rewarded with land conquered and taken "by force of arms" from the Muslims (Kaminsky, 2005, p. 9o). The fact that the cultivation of Iberian ham is tied to this context of religious, cultural, and political conflict and the triumph of Christianity over Islam renders it a powerful signifier of Spanish identity.

After Spain was re-conquered from Muslim rulers in the $15^{\text {th }}$ century and the spread of anti-Muslim sentiment, Muslims' food practices were scrutinized. Olivia Remie Constable's historical analysis, "Food and Meaning: Christian Understandings of Muslim Food and Food Ways in Spain, 1250-1550," explores how foodways demarcated boundaries between Christian and Muslim communities, particularly in $15^{\text {th }}$-century Spain. According to Constable, Muslims (and Jews) lived in fear of Christian inquisitors who investigated their homes for halal/kosher food traditions such as the avoidance of lard and salt pork, two primary markers of their non-adherence to Christian belief (Constable, 2013, p. 211). Here, it is evident that pork was a signifier of Christianity, while the lack thereof was a clear marker of one's Muslim or Jewish status. Constable's inclusion of inquisition and expulsion testimonies from Muslims and moriscos is significant, because they illustrate how under this system, food became a salient reminder of Muslims' "otherness." It is important to recognize that the similar food practices and prohibitions of Muslims and Jews, such as the consumption of eggplant or cooking without salt pork, was evidence of both communities" "heretical" tendencies. Constable notes that access to kosher and halal butchers became limited in the wake of the inquisition (Constable, 2013, p. 227). According to one inquisition record, a morisca woman from Granada confessed that "Christians do not know how to cook a stew without using salt pork (tocino), [but] in her land they made these dishes with olive oil" (Constable, 2013, p. 211). This testimony resembles comments from restaurateurs regarding their observations of Spanish food practices. Just as this Christian convert perceived the differences between Christians and Muslims in their contrasting food practices and understood how this challenged her ability to assimilate, interviewees recognized how the halal/pork binary and their newfound concern over maintaining a halal diet are features of their changed circumstances. Several interviewees described their sense of "otherness" through their food practices, as does this morisca woman. Today in Spain, Muslims' avoidance of pork and alcohol and their reliance on halal food establishments are indications of their cultural and religious differences. Muslim immigrants' discussion of the tensions and challenges around observing halal food practices indicates the persistence of this food-mediated religious and cultural barrier. 


\section{TWO CONFLICTING FOOD CULTURES AND DEPENDENCE ON HALAL FOODWAYS}

\begin{abstract}
Migrants take great care to prevent the moral contamination of haram (unlawful or forbidden meat that can seem threatening to them.) These concerns have moved to the forefront in the diaspora, whereas these dietary laws are "nearly unconscious" in [the home country] (Fischer, 2011, p. 111).
\end{abstract}

Readers should be mindful of other global examples of the cultural, religious, and gastronomic tension felt by Muslims and the questions of permissibility and non-permissibility it engenders. Gabriele Marranci, Mohamed Kamaludeen Nasir, and Alexius Pereira investigated the experiences of Malay Muslims in Singapore, a minority group similarly challenged by the ubiquity of pork in the surrounding society. Marranci claims that studying the "dynamics of halal dining...is relevant for understanding the effects it might have on [Muslims'] socialization within the mainstream society" (Marranci, 2012 , p. 88). Moreover, Nasir and Pereira's work proposes several theoretical concepts for interpreting Muslims' reliance on halal food products and their avoidance of pork. They claim that Malay Muslims adopt a "defensive dining" model and actively seek out "halal environments" as they confront the new country's pork-dominant environment (Nasir \& Pereira, 2008, p. 1). The same can be said of many Muslim immigrants living in Spain. The authors aptly describe this intensified concern around halal food observance by referring to it as a "halal consciousness" (Hashim \& Othman, 2011, p. 1).

In her research on the migrant experience in Italy, Roberta Giovine recognizes the social and religious significance of the halal dietary code for North African Muslims who abide by these laws “in order not to transgress Allah's rules...to not lose their status as members of the nation of Islam and, consequently, their community-defined identity" (Giovine, 2013, p. 248). Also pertinent is Leila Abu-Shams' work on food and immigrant identity in Zaragoza, Spain, in which she investigates the fundamental role of food in Muslim Moroccan immigrants' daily lives. She asserts that food is a "sign or a mark of identity that actualizes and preserves group identity confirming the separation between us and them" (Abu-Shams, 2008, p. 186). Specifically, she captures the importance of the categories of halal and haram. She explains, "When they select foods, they are following cultural guidelines.... Orders and prohibitions related to food ultimately put into sharp relief the distinct identity of a religious community and differentiates it from others" (Abu-Shams, 2008, p. 186). Riaz and Chaudry's Halal Food Production sheds light on the role of food and ritual within Islam and the dichotomy between that which is permissible (halal) and that forbidden (haram). When it is difficult to determine whether a food item is halal or haram, it is called mashbuh. The Qur'an states that pork and its derivatives, blood, and carrion are strictly forbidden (Riaz \& Chaudry, 2003 p. 122). For Muslim immigrants in Spain, eating halal is often about negotiating differences (Gasparetti, 2012, p. 257). Ayse Çaglar's essay on the kebab in Germany provides insight into the symbolic dimension of food, its ability to serve as an ethnic signifier, and its significant role in immigrant identity formation. Referring to Sidney Mintz's work, she reminds readers of the notion that "what people eat expresses who and what they are to themselves and to others" (Çaglar, 2013, p. 211).

Expanding on this notion of conflict between dominant Spanish food culture and Muslim food norms, Hamal, a 27-yearold kebab restaurant employee from Pakistan, points out that "all the world could eat Muslim food, but Islam cannot permit ham." He reiterates that he can eat tapas such as potatoes, but that his food options remain limited because they must be halal. According to the Muslim Pakistani restaurateurs I spoke with, Muslim immigrants rely heavily on Spain's emerging halal kebab industry. Restaurateurs Nadir, Hamal, and Mukhtar have witnessed the heightened concern of Moroccan Muslim customers over adhering to halal food practices. They explained that Muslim customers always verify that the meat in kebab restaurants is halal, "that they do not always trust that it is halal," a behavior that reflects Nasir and Pereira's (2008) concept of "defensive dining."

Speaking with a cook at Aljaima, a Moroccan restaurant in Almería, about his food practices revealed that he too perceives the tension between Spanish and Muslim foodways. He explained that as his wife has been cooking Moroccan food since she was young, they eat it nearly every day. When I asked if he prefers Spanish or Moroccan cuisine, he told me that he prefers Moroccan food, explaining immediately that "one cannot eat pork or drink alcohol because of religion." Similarly, Mukhtar, (the Pakistani owner of a kebab restaurant in Almería) admits that he has never tried tapas in a restaurant. He echoes Hamal's comments, saying, "all tapas have too much ham, or the frying pan has oil and grease from the pork. Spanish restaurants always have pork...it's really difficult...l eat in restaurants very seldom." He discussed how he and his family members must scrupulously check food labels in Spanish supermarkets to ensure that food items are not haram. These accounts reveal how the need to abide by halal dietary law and the desire to eat familiar foods contributes to many Muslims' 
lack of engagement with Spanish food and their reliance on the home sphere for cooking and eating. They illustrate the difficulty of partaking in the dominant Spanish food culture given the heightened "halal consciousness" of many Muslims upon arrival (Hashim \& Othman, 2011).

Furthermore, Moukib, a Moroccan restaurant owner, noted how halal food serves as a marker of ethnicity and otherness. He explained that his identity as a Moroccan is marked when he walks into a restaurant. Waiters look at him and based on his ethnicity and presumed religious practices, assume he cannot eat pork. Moukib does not eat pork, but not because of religion. Rather, he does so to avoid what he describes as the unhealthiness of the grease. Nevertheless, this avoidance is viewed by outsiders as an expression of Islam. Moukib's comment draws attention to the messiness of identity, how food practices serve as markers of identity that are both self-professed and projected onto individuals. While on the one hand a waiter's acknowledgement of Muslims' halal consciousness is ideal, Moukib highlights that the consumption of pork is a fervent expression of "Spanishness." According to Moukib, if he were to eat Iberian ham in a restaurant, people would consider him Spanish. He says, "Spaniards think that you have to eat pork to be Spanish." While clearly not all Spaniards consume pork products, the strong affinity for this forbidden item is apparent to many Muslims when they eat in bars or shop in supermarkets.

\section{CONVIVENCIA AND ADDRESSING THE TWO FOOD CULTURES TENSION}

In light of the challenges of negotiating these conflicting foodways, the question remains as to what can be done to address and even transcend this cultural, religious, and gastronomic tension? Halal foodways are not currently part of the paradigm of Spanish food culture; however, their historical presence in Andalucía during Muslim rule has not gone unnoticed. Discussions with Moroccan restaurateurs revealed their attempts to shift the lines of belonging for Muslims in Spain, particularly the Moroccan immigrant community, by drawing on an alternative narrative. Through references to the period of al-Andaluz and the concept of convivencia, they emphasize the linkages between Muslim, Moroccan, and Spanish food practices. By focusing on the restaurant space as a locale of identity expression and cultural representation, I explore the narratives that two Moroccan restaurateurs promote in their restaurant space and cuisine. Crucial to this exploration is the work by Robin Clair Patric et al. on the cultural narratives of restaurant spaces. They assert that food and food establishments are "discursive practices in their own right... places and means of identity construction" (Patric Clair et al., 2011, p. 138). They argue that the restaurant's ambiance is expressed through various agents: "sensory stimuli, including music, aromas, interior decorating and more" (Patric Clair et al., 2011, p. 140). Drawing attention to aesthetic choices and cuisine, this ethnographic study identifies the agents through which restaurant owners in Spain construct specified cultural narratives. By harkening back to the period of convivencia and underscoring the links between traditional "Christian" and "Muslim" cuisine in Spain, restaurateurs offer a means of lessening the gap between the two food cultures in contemporary Spain.

Literature in the anthropology of space and place focuses on the restaurant, emphasizing the roles of restaurateurs in determining the "culture" of the restaurant space. This can be viewed as a form of "identity maintenance." Grit Liebscher and Jennifer Dailey-O'Cain's Language, Space, and Identity in Migration offers insights into the concept of "space" as it relates to the migration experience. Recognizing the nuances of the immigrant experience, they explain that some migrants attempt to repress their place of origin, some endeavor to recreate it, and "others may do both at different times" (Liebscher \& DaileyO'Cain, 2013, p. 17). This attempt to replicate and recreate one's place of origin by merging it with the new context is crucial to understanding Moukib and Mohammad's restaurant identity work. Moreover, in The Restaurant Book: Ethnographies of Where We Eat, David Berris and David Sutton "examine the ways that processes of identity and memory are 'emplaced' in different sites, as restaurants come to stand for the larger places they inhabit and for social relations within cities and between nations" (Berris \& Sutton, 2007, p. 4). Drawing on this concept of "emplaced" identity, I investigate how restaurateurs' discussions of their restaurant space reflect a larger vision of Moroccan, and more broadly, Muslim immigrants' place in Spain.

Throughout our discussions, Mohammad, the owner of Fez Restaurant, invoked the image of Spain as "an incredible mixture of Christians and Muslims." This recollection is significant in that it promotes a vision of coexistence rather than tension. Moukib, the owner of Aljaima, also draws on the convivencia framework, viewing Moroccan and Spanish foodways collectively and acknowledging their emergence from the era of al-Andaluz. Both owners seek to highlight, as food historians have, that this era involved a series of cross-cultural and cross-religious exchanges between Muslims and Christians (Marin, 2004).

Moukib has lived in Spain for 28 years. He studied biology and interior design and worked as a translator and waiter before opening Aljaima. One of his aims is to demonstrate that Spanish 
and Moroccan-Muslim customs are bound in Andaluzi culture. I identify the moments in which he emphasizes a "shared history" between Spaniards and Moroccans or refers to the period of convivencia to signal gastronomic exchanges between Muslims and Christians. For example, when designing the Aljaima restaurant, Moukib explicitly sought to showcase architectural styles from Morocco that highlight the period of al-Andaluz. He explains that the interior of the restaurant is designed to look like a Moroccan patio with an air of Andaluz (see Figures 1-3). In modeling the space after this era, he emphasizes the historical presence of Muslims in Spain. He explains:

Almería belongs to the era of the Arabs, and there are many artifacts of Arab architecture in Almería, Spain. The floor tiles, furniture, paintings, lamps, and jewelry were bought in Moroccan artisan markets. Everything else was designed by hand, including the ceiling, which is covered in handpainted designs. I wanted it to be modeled after traditional homes in Morocco to give it this identity (Field notes).

In a later telephone conversation with Moukib, I asked him again about the "identity" of his restaurant, wondering if he would distinguish between the elements that are purely Moroccan and those of Andaluzi origin. He previously used the terms interchangeably, leading me to believe that the restaurant promotes both a Moroccan and Andaluzi identity. He explained that Moroccan architecture is based on Andaluzi architecture, that they are one and the same, adding, "In Moroccan architecture, there is a mixture of Andaluzi Amazih" (North African Andaluzi)." In his mind, they could not be disentangled from one another, emplacing Andaluzi identity as an expression of Moroccan traditions, the shared history between Spain and North Africa, and Spain's Muslim past. For example, he likens Aljaima's traditional Muslim fountain to those in Granada, Spain at the Alhambra. For Moukib, the fountain signifies the historical and ongoing practice of Islam in Spain (see Figure 4). However, much of the restaurant's furniture is directly from Morocco. As Liebscher and Dailey-O'Cain suggest, cultural representation in the restaurant space is not clear-cut, but multi-faceted.

Furthermore, Moukib views his restaurant's cuisine as a viable symbol of the historical moment of convivencia. The menu, which includes couscous, bastela de pollo, fish tagine, goat tagine, beef tagine, salads, bread, and traditional sweets, is "a collection of dishes from the Andaluzi era" in his words. The convivencia and al Andaluz narratives not only allow Moukib to claim a common history, but also serve as useful marketing techniques. For example, Aljaima's Instagram page highlights this collective history by advertising an "authentic Moroccan Andalucian cuisine." Moreover, many of Moukib's recipes are selected from a cookbook called La Cocina Popular de Almería (Gallego, 2010). He specified that these recipes are from Almería "from the era of the Muslims, when Muslims ruled Andalucía." He sent me recipes for beef and green peppers, beef stew, lamb with peas, pepper salad, sultan salad, broad bean tortilla, shish kebab, and pig's feet. Under the pig's feet recipe, he wrote a note regarding halal practices, emphasizing that “in Morocco one cooks lamb's feet instead." Here, he illustrates how halal and non-halal food practices from Spain to Morocco coexist within the Andaluzi framework. In doing so, he rewrites halal food practices into the current Spanish foodscape. Moukib's references to Andaluzi cuisine reveal a common culinary history, the exchanges that previously existed between Muslims and Christians, and the ongoing adjustments to suit religious needs. Referring again to Spain's period of Muslim rule, he recognizes that Muslims and Jews shared similar food restrictions, and that even today, they can "eat from the same plate."

By invoking this Andaluzi narrative, Moukib taps into the history of culinary exchange that occurred during the Muslim rule of Spain. Both Manuela Marín and Olivia Remie Constable examine recipe books in their work to trace the adoption of Muslim dishes by Christians and their use of "loanwords," that is, the incorporation of Arabic cooking terms into the Castilian vocabulary. Like Moukib, their discussions demonstrate the incorporation of Muslim foodways and food language into the Spanish food system (Marín, 2004, p. 50).

In Moukib's view, the gap between Moroccan-Muslim food customs and Spanish cuisine is not that wide. He states that the dishes he serves in his restaurant are similar to those eaten in $11^{\text {th }}$-century Andalucían villages. Moukib's emphasis on a single "Andaluzi cuisine" is a means of promoting a more expansive definition of Southern Spanish culture, one that acknowledges its Arab and Muslim roots. His emphasis on a common cuisine reflects his desire for a more nuanced definition of Spanish culture that locates halal culinary traditions within its boundaries. According to this vision, Aljaima restaurant can be viewed as an extension of Spanish culture. In fact, the convivencia paradigm seems to extend to Moukib's personal sense of identity. He dislikes the term "integration," because it signifies perderse en otra (losing oneself in another thing). Instead, Moukib asserts that he is "coexisting in harmony," rather than assimilating into Spanish culture. Perhaps reference to this historical moment makes the Spanish, Moroccan, and Muslim aspects of his identity seem less disparate. 
Figure 1. Aljaima restaurant

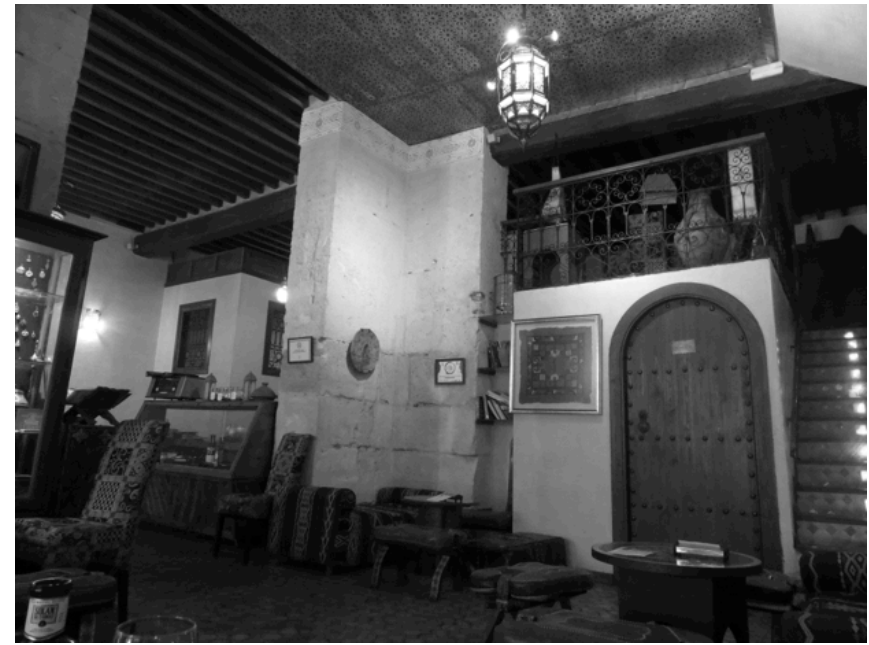

Source: Photograph taken by the author in 2015.

\section{Figure 3. Aljaima restaurant}

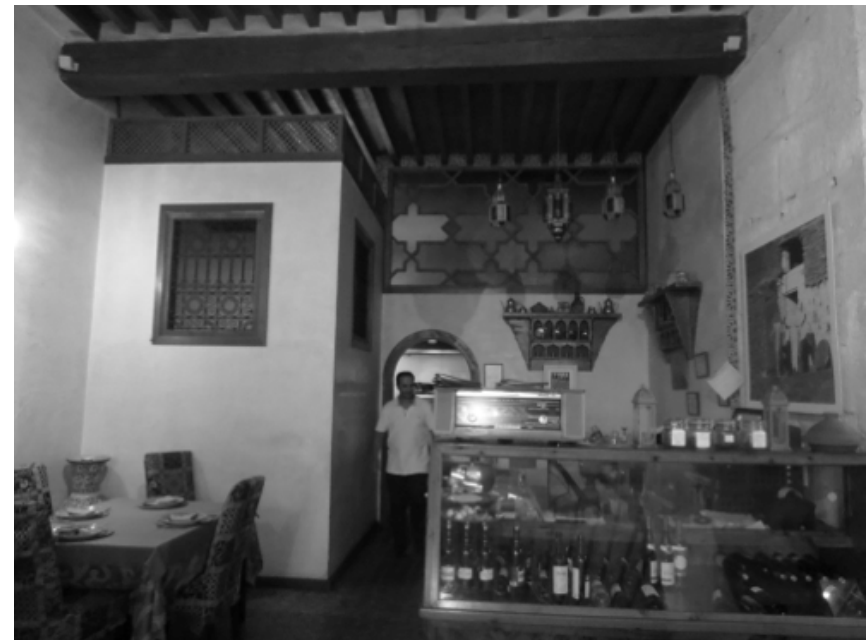

Source: Photograph taken by the author in 2015.

\section{Figure 4. Aljaima restaurant}

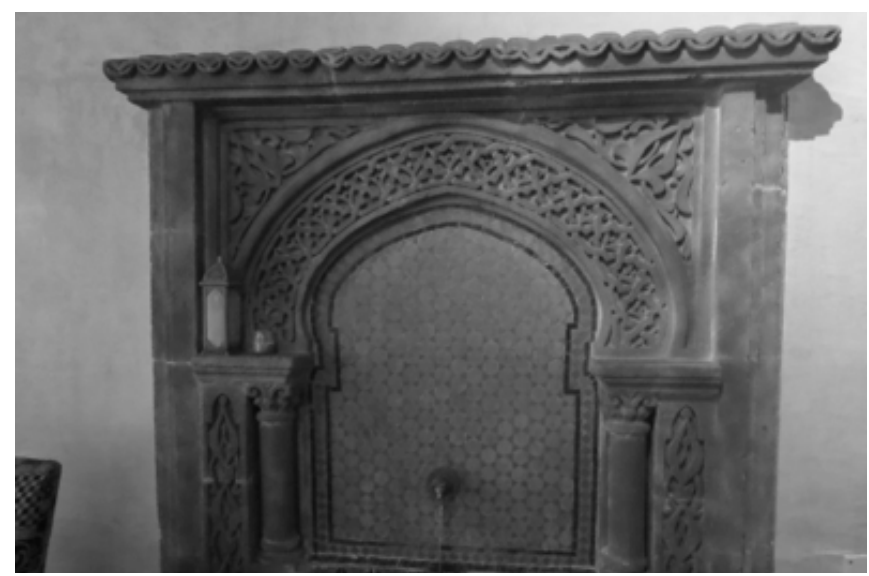

Source: Photograph taken by the author in 2015.
Figure 2. Aljaima restaurant

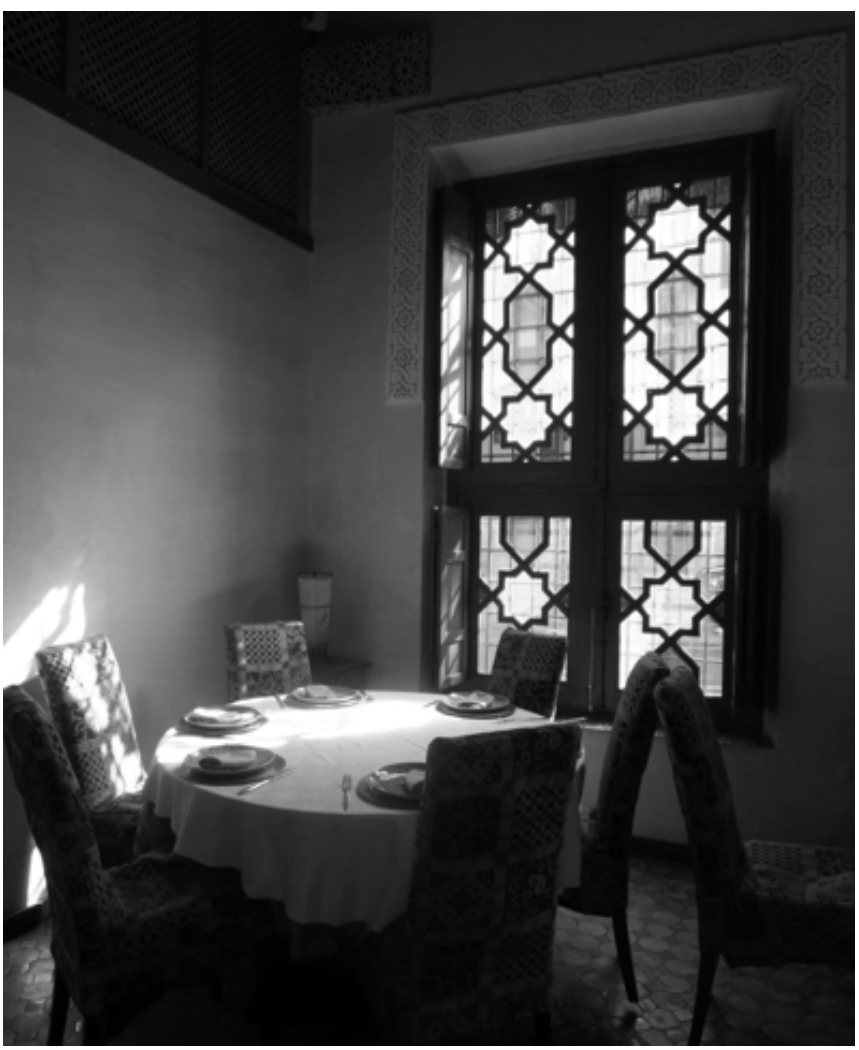

Source: Photograph taken by the author in 2015.

Figure 5. Aljaima restaurant

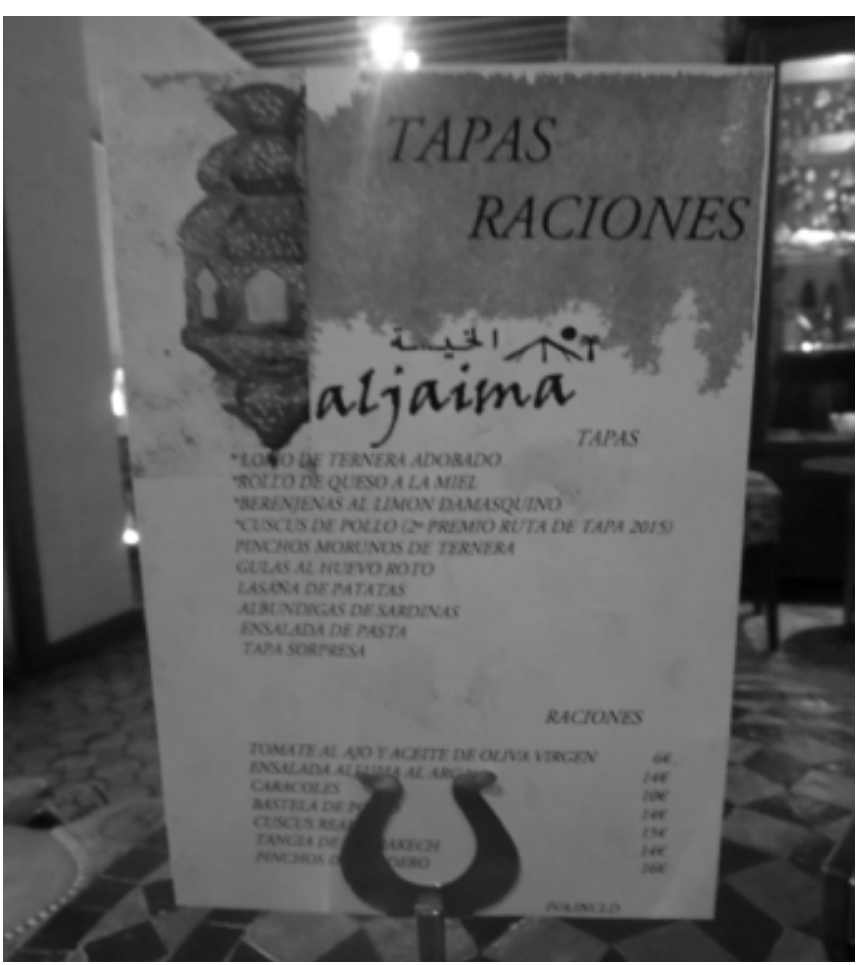

Source: Photograph taken by the author in 2015. 


\section{FOOD PREPARATION AND FUSION}

Food preparation and presentation is another area in which Moukib and Mohammad attempt to address the two food cultures tension and actively facilitate cross-cultural consumption between Muslim immigrants and Spaniards. Both owners do so by either blending elements of Spanish food culture and halal food practices and/or merging Spanish and Moroccan food practices. Moukib wishes to expose Spaniards and other Europeans to Andaluzi cuisine to underscore the historical presence of Muslims in Spain and the gastronomic links between Spain and Morocco. Mohammad perceives Muslims' need for more halal eating establishments in Spain. Both owners have thought of creative ways to unify these seemingly divergent foodways. This fusion is accomplished through two inverse processes. I refer to these as the tapasization of Moroccan/ Andaluzi cuisine, which is the incorporation of Spanish elements, and the halalization of Spanish cuisine, or the introduction of the Muslim dietary code. In both cases, restaurateurs' blending of food practices can be considered an effort to recreate a sense of convivencia between Muslims and non-Muslims in Spain. These hybrid processes greatly resemble the conceptual framework Richard Wilk uses to discuss the construction of Belizean cuisine under colonialism. Wilk discovers that "cooks and workers working across cultures and classes engaged in various kinds of creolization that led to convergence" (Wilk, 2002, p. 77). In particular, Wilk's definition of “mixing, wrapping, and substitution" can be applied to decipher the hybrid food practices of Moroccan restaurateurs.

Moukib's restaurant, Aljaima, further embodies convivencia through its inclusion of a tapas menu entitled la ruta de tapas (the tapas route). Given the ongoing economic crisis in Spain, Moukib is aware that many Spaniards are less inclined to buy elaborate meals. His choice to incorporate the Spanish tapas system is at one level economic, but also appropriate to the convivencia paradigm he espouses. This additional menu offers Spaniards a familiar and more economic means of accessing Andaluzi food. Moukib describes it as a "fusion of tapas with Moroccan spices," since each tapas dish has Moroccan flavors with Spanish style presentation. His ruta de tapas can be viewed as an example of the restaurant's adaptation to the Spanish culinary context (see Figure 5). As such, the use of the tapas menu could be seen as an example of Wilk's concept of "wrapping," that is, "the enclosing of something foreign within a familiar wrapping" (Wilk, 2002, p. 78). However, at the same time, the combination of Spanish and North African culinary traditions reflects Moukib’s Andaluzi framework.
Mohammad hopes to combine Spanish foodways and halal food practices. According to Mohammad, halal meat shops and restaurants are not common in Seville. In the future, he plans to open a restaurant that serves Spanish dishes such as salmorejo or chorizo using halal meat to cater to the Muslim community. This proposal for a Spanish-halal cuisine is an example of Wilk's concept of "mixing," which occurs when "dishes of different ethnic origins are served together" (Wilk, 2002, p. 77). During our first conversation, Mohammad noted that everyone who ate that evening at Fez Restaurant was Muslim and that "they were all looking for halal food." He claims that such a restaurant would also cater to Spanish converts to Islam and Muslim tourists so that "people from abroad who are Muslim can try Spanish food." In her essay "Arab Traces in Spanish Cooking," Manuela Marín claims that "there existed in al-Andaluz a superior model of gastronomic satisfaction" on the part of Muslims and Christians (Marín, 2004, p. 38). Both Marin and Constable note that as early as the $11^{\text {th }}$ century, provisions were frequently made for Muslims, such as the use of separate communal ovens and pots to avoid the mixture of forbidden dishes like pork and licit foods. Constable's work reveals how solutions to the halal/pork binary existed before the reconquista. In fact, she notes that in the $13^{\text {th }}$ century, rights were granted to "subject Muslim communities" in Aragon and Castille to have "Islamic butchers and special shops or tables for selling haläl meat” (Constable, 2013, p. 228). Similar to how Muslims' religious and gastronomic needs were historically recognized, allowing Muslims and Christians to share meals, Mohammad endeavors to recover this "model of gastronomic satisfaction."

Through this proposed merging of Spanish food customs and halal food practices, Mohammad would provide a safe way for Muslims who observe halal to experience a primary element of Spanish culture-tapas. He, like Hamal and Mukhtar, clarifies how cultural and religious barriers manifest through foodways. Although Mohammad does not himself express strong frustration with the omnipresence of pork in Spain, he recognizes that it poses a challenge for Muslims. This hybrid concept of a Spanishhalal restaurant, like the kosher-Chinese restaurants of New York that emerged in the mid-2 $0^{\text {th }}$ century, offers one solution to this gastronomic conflict (Coe, 2009). Currently, the Spanish kebab industry is one of the only affordable means for Muslims to obtain halal meat when dining out. Mohammad's Spanishhalal restaurant would be a step further, creating a new niche that explicitly merges Spanish foodways and the Muslim dietary code, introducing another form of convivencia. Furthermore, Mohammad's Spanish-halal restaurant would bridge the economic gap between halal restaurants. While Aljaima's food 
is halal, most of its customers are wealthy Spaniards or Muslim tourists. Moukib recognizes that his restaurant attracts a middle and upper class demographic and does not cater to Muslim immigrants. He explains, "They [Moroccan immigrants] eat in their homes. Given the economic crisis, they do not have the possibility to eat here anymore." In contrast, Mohammad's proposed restaurant could attract kebab restaurant workers such as Hamal, Nadir, and Mukhtar and the Muslim customers who currently rely on kebab restaurants.

A further example of the halalification of Spanish cuisine emerged recently in Huelva, the center of Spain's pork-producing region. According to National Public Radio (NPR), Faysal Mrad Dali, a Tunisian immigrant, developed Spain's first halal Iberian ham, which represents a fusion of Muslim and Spanish culinary traditions. Dali's halal-certified Iberian ham product is made from lamb and sometimes beef, but simulates Iberian ham in its overall appearance. Like the restaurant owners and workers I spoke with, Dali recognizes that Muslims in Spain are unable to participate in the consumption of jamón iberico, and that this gastronomic barrier excludes Muslims from a fundamental part of Spanish life. He explains to journalists, "The first time I came with my family to Spain, to Andalusia, I said, "Why do the Muslims not have this [jamón iberico]?'” Dali moved to Cumbres Mayores, a town in Huelva, four years ago to establish his meat business (Frayer, 2014, p. 1).

This phenomenon further illustrates how food becomes the basis for negotiating identities. Dali's creation of the halal Iberian ham, a hybrid product, marks his desire for Muslims to carry out their dual Muslim and Spanish lifeways. This halalization of Iberian ham is a clear example of "substitution," that is, "a special form of mixing that occurs when an item that is normally part of a dish or meal is substituted by one of different origin" (Wilk, 2002, p. 78). This desire to participate in one of Spain's most prominent culinary traditions while not detaching from Islamic dietary law is ultimately a means to carve a Spanish Muslim identity. The halal jamón offers Muslims the opportunity to safely engage with an element of Spanish food culture without abandoning their religious and cultural affiliations. However, according to the article, this compromise is not an acceptable practice for all Muslims, and the fear of eating something that so clearly resembles the "forbidden" persists.

Most important, Dali states that the halal jamón symbolizes the historical coexistence of Spanish and Muslim cultures. He explains, “This has been a dream for me as a Muslim. I am living and making my product in a region where Muslims, Jews, and Christians have a history of living and eating together" (Frayer, 2014, p. 1). Here, the convivencia paradigm allows Dali to confirm the significance of this hybrid product. The halal jamón iberico-the convergence of traditional Spanish and Muslim eating customs-is a further expression of convivencia that he hopes will lead to a broader definition of what it means to be Spanish.

Restaurant owners' efforts to unite Moroccan, Spanish, and specifically Muslim gastronomic elements are connected to the process of negotiating a dual Muslim and Spanish identity, or in some cases, a dual Moroccan and Spanish identity. Moukib, Mohammad, and Dali's recollection of convivencia and al-Andaluz compels them to find creative ways to merge seemingly divergent foodways and facilitate a form of coexistence in the contemporary, thereby enabling Muslims and non-Muslims to "eat from the same plate."

\section{CONCLUSION}

The grappling of Muslim immigrants with the halal/pork binary ultimately reveals the challenges of being Muslim in Spain. This article identified how two restaurant owners seek to revive the concept of convivencia, as they see certain narratives on the place of Moroccans and Muslims in Spanish culture reflected in their restaurants' architecture, décor, and cuisine. Equally important are the solutions developed by the two Moroccan restaurant owners to transcend the two food cultures conflict. Moukib's repeated espousal of al-Andaluz and a shared history and tapasization of Moroccan cuisine, and Mohammad's proposed halalization of Spanish cuisine are efforts to address the cultural, religious, and gastronomic barriers salient to many Muslim immigrants. In the context of the two food cultures conflict, this food-related work elucidates restaurateurs' ability to tap into a collective food history and develop innovative food practices that address gastronomic tension as well as rewrite and integrate halal into the Spanish foodscape. Further meditations on food spaces, the use of food narratives, and the immigrant experience in Spain are needed to uncover the ability of restaurateurs to derive meaning from foodways and draw on food histories to facilitate their community's belonging in a new country.

Future ethnographies of the Moroccan restaurant in Spain ought to explore whether the use of the convivencia narrative is common and any additional means through which it is evoked. Such analyses could also investigate whether the Jewish experience, past and/or present, is in Muslim restaurateurs' purview. Future studies might also consider customers' perceptions of restaurant spaces and investigate 
whether Muslims outside the restaurant industry reference the convivencia period. Together, such studies could continue exploring the extent to which Spain's Muslim-Arab past is present in the minds of Muslim immigrants. Given that European nations are currently grappling with the arrival of Muslim immigrants and refugees and the place of Islam in Europe, such explorations of the lived experiences of Muslims are particularly relevant. What new patterns will emerge in the Spanish context? Will the halal/ pork binary begin to subside and will restaurateurs continue to disseminate the narrative of convivencia? Can halal foodways and other aspects of Spain's food history be written into Spanish culture on a grand scale? Or will the two food cultures conflict gain more traction in the wake of growing anti-Islamic sentiment and the rising popularity of the far right in Europe?

\section{REFERENCES}

Almería-City: An Informative Guide. (2016). Andalucia.com. Retrieved from http://www.andalucia.com/cities/almeria.htm.

Abu-Shams, L. (2008). La alimentación como signo de identidad cultural entre los inmigrantes marroquíes. Zainak, 30, 177-193.

Bergeaud-Blackler, F. (2007). New challenges for Islamic ritual slaughter: A European perspective. Journal of Ethnic and Migration Studies, 33 (6), 965-980. doi:10.1080/13691830701432871

Bergeaud-Blackler, F., Fischer, J., \& Lever, J. (Eds.). (2016). Halal matters: Islam, politics and markets in global perspective. London, UK: Routledge Taylor and Francis Group.

Beriss, D., \& Sutton, D. (Eds.). (2007). The Restaurants Book: Ethnographies of where we eat. New York, NY: Bloomsbury Academic

Bonne, K., \& Verbeke, W. (2008). Muslim consumer trust in halal meat status and control in Belgium. Meat science, 79(1), 113-123. doi:10.1016/j.meatsci.2007.08.007

Bonne, K., Vermeir, I., Bergeaud-Blackler, F., \& Verbeke, W. (2007). Determinants of Halal meat consumption in France. British Food Journal, 109(5), 367-386. doi:10.1108/0070700710746786

Bravo, F. (2014, April 11). Islam in Spain: 800\% population increase in a mere 13 years. Retrieved from https://muslimstatistics.wordpress. com/2014/04/11/islam-in-spain-800-population-increase-in-mere13-years/

Çaglar, A. S. (2013). Mc Kebap: Doner Kebap and the social positioning struggle of German turks. In J. Costa \& G. Bamossy (Eds.), Marketing in a Multicultural World (pp. 209-230). Thousand Oaks, CA: Sage.

Clair, R. P., Holyoak, I. C., Hill, T. E., Rajan, P., Angeli, E. L., Carrion, M. L., ... \& Sastry, S. (2011). Engaging cultural narratives of the ethnic restaurant: Discursive practices of hybridity, authenticity, and commoditization. In N. K. Denzin, \& T. Faust (Eds.) Studies in symbolic interaction (pp. 135-161). Bingley, UK: Emerald Group Publishing Limited.
Coe, A. (2009). Chop suey: A cultural history of chinese food in the United States. New York, NY: Oxford University Press.

Constable, O. R. (2013). Food and meaning: Christian understandings of Muslim food and food ways in Spain, 1250-1550. Viator, 44(3), 199235. doi:10.1484/J.VIATOR.1.103484

Euro-Islam. (2013, March 01). Demographic study of the Muslim population in Spain. Retrieved from http://www.euro-islam.info/2013/02/28/ demographic-study-of-the-muslim-population-in-spain/.

Fischer, J. (2011). The Halal frontier: Muslim consumers in a globalized market. Basingstoke, UK: Palgrave Macmillan.

Frayer, L. (2014, December 16). At last, Muslims can savor a Halal spin on Spain's famous jamón. Retrieved from http://www.npr.org/ sections/thesalt/2014/12/16/371018946/at-last-muslims-cansavor-a-halal-spin-on-spains-famous-jamon

Gallego, J. G. (2010). La cocina popular de Almería. Mojácar, Spain: Arráez.

Gasparetti, F. (2012). Eating tie bou jenn in Turin: Negotiating differences and building community among Senegalese migrants in Italy. Food and Foodways, 20(3-4), 257-278. doi:10.1080/07409710.2012.715976

Giovine, R. (2013). Children of Muslim migrants in Italian schools and the Halal meat issue. Proceedings in ARSA: Advanced Research in Scientific Areas, 2(1). Retrieved from http://www.arsa-conf.com/ archive $/$ ?vid $=1 \&$ aid $=2 \&$ kid $=60201-81$

Hashim, A. H., \& Othman, M. N. (2011, November). Halal food consumption: A comparative study between Arab Muslims and non-Arab Muslims consumers in Malaysia. In Australian and New Zealand Marketing Academy (ANZMAC) Conference, Perth, Australia, November. Retrieved from https://www.academia.edu/5646761/ Halal_food_consumption_A_comparative_study_between_Arab_ Muslims_and_Non_Arab_Muslims_consumers_in_Malaysia(Vol. 20359).

Kaminsky, P. (2005). Pig perfect: Encounters with remarkable swine and some great ways to cook them. New York, NY: Hyperion.

Lever, J., \& Miele, M. (2012). The growth of halal meat markets in Europe: An exploration of the supply side theory of religion. Journal of Rural Studies, 28(4), 528-537. doi:10.1016/j.jrurstud.2012.06.004

Liebscher, G., \& Dailey-O'Cain, J. (2013). Language, space and identity in migration. London, UK: Palgrave Macmillan,

Marín, M. (2004). From Al-Andalus to Spain: Arab traces in Spanish cooking. Food and History, 2 (2), 35-52. doi:10.1484/J.FOOD.2.300096

Marranci, G. (2012). Defensive or offensive dining? Halal dining practices among Malay Muslim Singaporeans and their effects on integration. The Australian Journal of Anthropology, 23(1), 84-100. doi:10.1111/j.1757-6547.2012.00166.x

Nasir, K. M., \& Pereira, A. A. (2008). Defensive dining: Notes on public dining experiences in Singapore. Contemporary Islam, 2(1), 61-73. doi:10.1007/s11562-007-0033-8

Pariona, A. (2017 April 25). Religion in Spain. Retrieved from http:// www.worldatlas.com/articles/religion-in-spain.html. 
Patric Clair, R., Clarke Holyoak, I., Hill, T. E., Rajan, P., Angeli, E. L., Carrion, M. L., ... \& Sastry, S. (2011). Engaging cultural narratives of the ethnic restaurant: Discursive practices of hybridity, authenticity, and commoditization. In Studies in Symbolic Interaction (pp. 135161). Bingley, UK: Emerald Group Publishing Limited.

Riaz, M. N., \& Chaudry, M. M. (2003). Halal food production. Boca Raton, FL: CRC Press.
Wilk, R. (2002). Food and Nationalism: The Origins of "Belizean food." In by W. Belasco \& P. Scranton (Eds.), Food Nations: Selling Taste in Consumer Societies (pp. 67-89). London, UK: Routledge.

Wright, W., \& Annes, A. (2013). Halal on the Menu?: Contested food politics and French identity in fast-food. Journal of Rural Studies, 32, 388-399. doi:10.1016/j.jrurstud.2013.08.001 